\title{
The Problem of Teachers In Learning To Write Poetry In Elementary School
}

\author{
T Indrawati ${ }^{1}$, E Sukma $^{2}$, A Suriani $^{3}, \mathrm{~N} \mathrm{Fadillah}^{4}$ \\ \{tinindrawati1608@gmail.com\} \\ ${ }^{1,2,3,4}$ Universitas Negeri Padang, Jl. Prof Dr. Hamka Air Tawar, Padang, Indonesia
}

\begin{abstract}
The problem in learning to write poetry is the difficulty of students to come up with ideas and develop them into poetry lines. This study uses a qualitative method, data collection is done by half-structured interview techniques. The population is elementary school teachers in the city of Padang. Sample selection uses snowball sampling techniques. The number of samples is five people. The data analysis technique used is thematic analysis. This thematic analysis model consists of three stages, namely data reduction, data display, and data validation. The results of this study indicate that all respondents agreed that teachers need to change their perceptions in teaching. Teachers should strive to understand theories, methods and design learning creatively and innovatively so that learning is more meaningful and learning goals are easily achieved.
\end{abstract}

Keyword : Students, Technique.

\section{Introduction}

Poetry writing skills are skills that aim to express and express one's inner experience with beautiful written language that is recorded, expressed, and expressed in an interesting and memorable way. The impression is related to the meaning that the writer wants to convey to the reader. In writing poetry, writers are required to try to express and devote all their feelings, opinions and experiences to their readers so that readers can understand the contents and meanings conveyed by the author [1]. Therefore, writing poetry requires a creative process that cannot be achieved instantly. Writing is a creative process [3]. As a creative process, the writer must experience a creative process.

Based on that goal the ability to write poetry needs to be possessed by students. By writing poetry students are able to express their ideas and ideas. The low ability of students in writing poetry is caused by the lack of appreciation in learning to write poetry [4]. The lack of teacher's ability in learning in schools can be seen from the National Teacher Competency Test with a mean of 42.7 (Ministry of National Education, 2012) and in the 2015 Teacher Competency Test, only 44.5 well below the 75 standard value.

The low performance of teachers in organizing education is also caused by the low quality of teachers in terms of mastery of subject matter and teaching skills. The level of mastery of teaching materials and skills in using innovative teaching methods is still lacking, generally teachers use the lecture method [5]. Furthermore, UNESCO data in the 2016 Global Education 
Monitoring (GEM) Report shows, education in Indonesia ranks only 10th out of 14 developing countries.

The problem of learning to write poetry is important to know by the teacher so that the teacher can find solutions and can carry out learning to the maximum. Understanding the problem of learning to write poetry both the teacher so that he is able to convey learning well and is easily understood by students, easy to remember and fun [7].

The low ability of students to write poetry such as difficulty in finding ideas, so students need a long time to finish writing [8]. Students difficulties in developing essay topics and the use of word choices have not been a concern of students in writing [9]. In addition, student motivation in appreciating literature is still low. Students are less interested in reading literary works [10]. Unlike the research that has been done, this research will discuss problems that are not only experienced by students but also experienced by teachers in learning to write poetry in elementary school. Therefore, this study aims to find out the problems about learning to write elementary poetry.

\section{Literature Review}

\subsection{Writing poetry}

Poetry is a literary work with a language that is condensed, shortened, and given a rhythm with a unified sound and selection of words (imaginative). The words are chosen so that they have the power of pronunciation. One way for poetry to have the power of pronunciation, is to choose words that have the same sound (rhyme). Poetry has always been a center of literary education strength [6]. Poetry has the capacity to attract humanity because of its ability to synthesise experience in ways that instill musicality, rhythm, and pain [11].

Writing poetry will produce creative writing that can help students to represent crisis [12]. Writing poetry requires a creative process that cannot be achieved instantly [2]. Therefore, suitable methods are needed so that students and teachers find it easier to carry out learning to write poetry. Thus, optimal results can be achieved in learning to write poetry. Student involvement in writing poetry provides a number of benefits that are related to identity and self-expression [6]. Poetry writing is also valued for being able to improve students' language skills such as listening, developing vocabulary, learning to read and write, and thinking creatively. Poetry is beneficial for education. The aesthetic values of poetry become material that is not only useful for increasing language competence and learning motivation but is also worthy of being encouraged by the learner's imagination and creativity [13]. One effective way to improve poetry writing skills is to combine two important elements, namely the value of education and entertainment

\subsection{Learning to write poetry}

Learning to write poetry in school should be done appreciatively in accordance with the purpose of learning that is students are able to express and express one's inner experience with beautiful written language. Learning is done through appreciation activities, students can see, listen, feel events, atmosphere, imaginatively. Therefore, literary learning including poetry in schools is intended to sharpen feelings, reasoning, imagination, and social sensitivity [14]. For this reason literary teaching is carried out in the form of various activities such as listening, speaking, reading, and writing. The method is a process to facilitate the implementation of 
activities to achieve goals [15]. The method is a method used by teachers in teaching and learning activities to achieve goals [16]. So, the method is one component to achieve learning objectives. Learning activities using the method will give birth to interactions between the elements in the learning process.

Media is a tool used as a messenger from the sender to the recipient of the message. Media is anything that carries information between the source of information and the recipient [17]. The statement can be interpreted that everything that can bridge information between the source of information and the recipient can be said to be the media. If it is related to learning, then the media can be interpreted first as everything that is used to clarify the message of learning, second is the media specifically designed to achieve certain learning competencies.

\section{Method}

This study uses qualitative methods to find out the problems in teaching poetry in elementary school. Data collection is done through interviews with teachers. The interview technique used was a half-structured interview technique. The population in this study is elementary school teachers in the city of Padang. The population size for qualitative research is unknown and researchers do not obtain data on this matter. Therefore, to choose a sample or qualitative research respondents used snowball sampling technique. The snowball sampling technique refers to the research respondents so that the respondents appoint other respondents to be interviewed [18]. The respondents indicated to be interviewed are the best respondents to provide comprehensive information about this research.

For this purpose, the reviewer has interviewed a North Padang teacher. They gave information about the respondents who were going to meet later, namely from the area of South Padang as a representative from South Padang. Then the reviewer asks information from respondents in the South Padang area to prepare respondents to be interviewed in the West Padang and Nanggalo regions who represent the western region. After interviewing respondents from the western region, researchers asked respondents for the eastern region, namely the Kuranji and East Padang regions. This process is repeated so that the researcher gets the right data from the gibberish meeting. Sampling for qualitative studies must take about several aspects, including: (1) the sampling strategy should be in accordance with the framework of the research concept and research problem, (2) the research sample should provide rich information about the phenomena under study, (3) the research sample should provide the ability to generalize research results, and (4) diversity levels of the study population, the higher the diversity of the population, the greater the number of samples needed [19] [20].

In this research the data analysis technique used is thematic analysis following the model created by Miles and Hubeman. This thematic analysis model contains three stages, namely data reduction, data display, and data verification (verifying). Formatting the text The text of your paper should be formatted as follows:

a) 11 point 'Times' or 'Times Roman' or 'Times New Roman' depending on the fonts installed on your computer.

b) The text should be set to single line spacing.

c) Paragraphs should be justified.

d) The first paragraph after a section or subsection should not be indented; subsequent paragraphs should be indented by $5 \mathrm{~mm}$. 


\section{Result and discussion}

Based on the results of the thematic analysis of interviews found three problems experienced by teachers in learning to write poetry in elementary school. The three problems are poetry theory, teaching writing poetry, and writing poetry. These three problems are part of the content of Indonesian language content in elementary school.

\subsection{Writing poetry}

In writing poetry students still find it difficult to come up with ideas and develop ideas. Ideas are the basis of writing. In addition students also have difficulty in using appropriate word choices and the ability to use rhymes and images. As expressed by core teacher respondents ( $\mathrm{R} 1, \mathrm{R} 2 / \mathrm{P})$. To overcome these problems the teacher needs to direct students by using methods and media. The use of methods and media in learning cannot be separated. For example in writing rhymes, as expressed by teacher respondents (R3 / P).

\subsection{Poetry theory}

Obtained studies show that in learning to write poetry found problems. The problem is the knowledge of child poetry theory as stated by the teacher. Knowledge of poetry writing theory includes the nature of poetry writing and the elements that make up poetry.

\subsubsection{The nature of writing poetry}

The essence of writing poetry refers to the meaning, purpose, and characteristics of children's poetry. That is a fundamental thing that needs to be mastered by elementary school teachers in learning to write poetry. The research shows that teachers lack understanding of the meaning, purpose of writing poetry, and intrinsic elements of poetry. As stated by respondents respondent (R1 / P). The respondent stated that even though elementary school was not taught the nature of literature, the teacher needed to know about the meaning and purpose of writing poetry.

\subsubsection{Intrinsic poetry}

Based on the results of the study found that there are still teachers who do not understand the intrinsic elements that build poetry. Though these elements are needed in writing poetry. The intrinsic elements are the theme, mandate, rhyme, and point of view as stated by the teacher respondent $(\mathrm{R} 3 / \mathrm{P})$.

\subsubsection{Teaching poetry writing}

The teacher's ability to teach writing poetry is how the teacher presents the subject to students. But the ability to teach writing poetry is still problematic. Based on the results of research the ability of teachers to teach poetry writing is still not optimal. The lack of optimization can be seen in the use of media, the use of methods, and assessment in writing poetry. As expressed by the teacher based on interviews. As expressed by teacher respondents (R5 / L).

The above statement was also supported by respondents (R2P) who stated that the use of media and methods can improve communication between students and teachers, students and students, and students with the media 
Tabel 1. Summary of Themes produced in the interview analysis

\begin{tabular}{clll}
\hline No & \multicolumn{1}{c}{ Construct } & \multicolumn{1}{c}{ Theme } \\
\hline 1. & Poetry Writing Theory & 1. & The Nature of Poetry \\
& & 2. & Intrinsic element of poetry \\
2. & Teaching Poetry Writing & 1. & Method \\
& & 2. & Steps for writing poetry \\
3. & Writing poetry & & The ability to come up with \\
& & 2. & ideas \\
& & 3. & Word choice \\
\hline
\end{tabular}

Based on interviews with teachers about the difficulties students write poetry is the difficulty in generating ideas and developing ideas. Ideas are important in writing activities, without the idea that a person cannot write especially for elementary students who have not yet extensive experience. Therefore, teachers need to explore student experiences before writing activities are carried out. In this case the teacher can use methods and media. Third grade elementary school students who are taught to write stories through personal journals show an increase in fluency and writing skills [21]. Therefore, teachers need a lot of composing to increase their creativity in writing.

Creative writing including writing poetry is an activity to create a new world that departs from events around the author. Creative writing can be concluded as an activity of realizing what is in the brain with as an initial step written by our hands [22]. Therefore the teacher needs to understand the writing process which consists of the prewriting, writing, and postwriting stages. Pre-writing is the preparation phase of writing. The prewriting stage is the preparation stage before the writing activity [23]. Things that need to be considered at this stage are choosing a topic, considering the objectives, and arranging ideas. The prewriting stage is a very important and decisive stage in the later writing stages. At this stage the instructor expects the teacher to optimize this activity by exploring students' schemata to come up with ideas, making it easier for students to find topics and develop topics into poetry.

The weaknesses of students in writing poetry include that there are still many teachers who do not understand the theory of writing poetry. This problem makes it difficult for the teacher to determine what needs attention in writing poetry. Furthermore, the teacher states that although the theory of Satera is not taught to students, the theory needs to be mastered. Literary theory that needs to be mastered is understanding, the purpose of writing poetry, and the intrinsic elements of poetry. Poetry is one of the works of literature that has a high aesthetic value (art) and comes from interpretations of human life experiences that are changed in the form of the most important memorable or as a result of the poet's imagination and ideas set forth in a specific typographic form [24]. Furthermore writing including writing poetry is a productive and expressive activity [25]. The results of this study are supported by the results of research that teachers need to master extensive knowledge in the field of literature and be able to appreciate literary work [26].

The results of this study indicate that teachers are still experiencing difficulties in teaching writing poetry. The teacher still does not understand the methods and steps in writing poetry. Most teachers only ask students to write poetry. The teacher does not use methods and media. Therefore teachers need to master the ability to use methods and media. The method is a way or effort made by the teachers so that the learning process in students is achieved in accordance with the objectives. The method is a method used by teachers to interact with students in the teaching process [27]. The method is one way to achieve the goal [28]. This 
study has supported the findings of previous studies conducted that the use of teaching affects the understanding of literary works [29] [30] [31].

\section{Conclusion}

The weakness of students in mastering the ability to write poetry is the ability to find ideas and develop these ideas. The results of this study indicate that all respondents agreed that the willingness and creativity of teachers can change the awareness and perception that they also have the ability to succeed in teaching. Teachers who strive to understand theories, methods and design learning creatively and innovatively will provide meaningful learning for students. Thus the learning objectives will be easily achieved. Efforts to improve Indonesian language learning nowadays need to be given more serious attention. All Indonesian language teachers must have a commitment to deal with this problem. Furthermore, teachers should be able to utilize their knowledge and abilities in teaching.

\section{Acknowledgment}

Thank you to Universitas Negeri Padang for permitting this research.

\section{References}

[1] Warjayanti G, Susilowati S and Syambasril 2016 Jurnal Pendidikan dan Pembelajaran 65

[2] Sari N A, Saddhono K and Suyitno 2014 J. Penelit. Bahasa, Sastra Indonesia dan Pengajarannya I 540

[3] Semi M. A 2000 Sastra 45

[4] Noor J 2014 Metodologi Penelitian (Jakarta:Kencana)

[5] UNESCO 2002 Learning To Be: A Holistic and Integrated Approach to Values Education for Human Development: Core Values and The Valuing Process for Developing Innovative Practices for Values Education Toward International Understanding and A Culture of Peace (Bangkok: UNESCO Asia and Pacific Regional Bureau for Education)

[6] Xerri D 2013 English Teach 12140

[7] Syahril, C Marzuki and Som H M 1999 Isu Pendidikan di Malaysia: Sorotan dan Cabaran (Kuala Lumpur: Fajar Bakti Sdn. Bhd)

[8] Ardiasyah D 2018 Pedadidaktika: Jurnal Ilmiah Pendidikan Guru Sekolah Dasar 543

[10] Asri Y 2012 Jurnal Bahasa dan Seni 132

[11] Sjollema S D, Hordyk S, Walsh C A, Hanley J and Ives N 2012 Journal of Poetry Therapy 25 205

[12] Rodriguez K 2006 Int. J. Educ. Arts 715

[13] Dastpak M, Fatemeh B and Taghinezhad A 2017 International Journal of Languages Education and Teaching $\mathbf{5} 230$

[14] Djuanda D 2009 Apresiasi Sastra Indonesia (Bandung: UPI Press)

[15] Depdikbud 1995 Kamus Besar Bahasa Indonesia (Jakarta : Balai Pustaka)

[16] Wijaya T 2009 Analisis Data Penelitian Menggunakan SPSS (Yogyakarta: Unversitas Atmajaya) 
[17] Heinich et al 2005 Instructional Technology and Media for Learning (New Jersey, Columbus, Ohio: Pearson Merrill Prentice Hall. Upper Saddle River)

[18] Ritchie J and Jane L 2003 Qualitative Research Practice: A Guide for Social Science Students and Researchers (London: SAGE Publications Ltd)

[19] Miles and Huberman 1994 Qualitative Data Analysis: An Expanded Source Book (Thousand Oaks, California: Sage Publication, Inc)

[20] Bungin B 2009 Penelitian Kualitatif, Komunikasi, Ekonomi, Kebijakan Publik dan Ilmu Sosial Lainnya (Jakarta: Kencana)

[22] Laksana A.S 2006 Creative Writing (Jakarta: Media Kita)

[23] Hoskisson K and TompkinsvG. E 2007 Language arts: Content and teachingstrategies (Melbourne: Merill Publishing Company)

[24] Wicaksono A 2014 Menulis Kreatif Sastra dan Beberapa Model Pembelajarannya (Lampung: Garudhawaca)

[25] Saryono D 2009 Dasar Apresiasi Sastera (Yogyakarta: Elmatera Publishing)

[26] Tindaon Y.A 2012 Pengertian Pengaruh Kamus Besar Bahasa Indonesia (Jakarta: Kemendikbud)

[27] Sudjana N 2005 Penilaian Hasil Proses Belajar Mengajar (Bandung:Remaja Rosdakarya)

[28] Surakhmad W 1980 Pengantar Interaksi Mengajar-Belajar Dasar-dasar dan Teknik Metodologi pengajaran (Bandung: Tarsito)

[29] Purwanto N 2007 Psikologi Pendidikan Remaja (Bandung: Rosdakarya)

[30] Hosnan M and Suherman H 2013 Profesional Guru dalam Jabatan (Jakarta: Yudistira) 